\title{
Resource saving wool washing technology
}

\section{Mykola Oseiko, Tetiana Romanovska}

\section{National University of Food Technologies, Kyiv, Ukraine}

\section{Keywords:}

Wool

Grease

Washing

Resourcesaving

\section{Article history:}

Received

12.09.2017

Received in revised form 12.11.2017

Accepted

29.12.2017

\section{Corresponding} author:

Tetiana

Romanovska

E-mail:

rombiotann@ukr.net

DOI:

$10.24263 / 2310-$

$1008-2017-5-2-5$

\section{Abstract}

Introduction. Washing of wool is carried out in an aqueous environment in order to remove contaminants and wool fat (zhyropit). Remove sewage from sewage. The purified fat of wool (food additive E-913, lanolin) is widely used in the production of food, perfumery, cosmetics and specialty products and preparations.

Materials and methods. Sles 70 was washed with wipes. To find rational wool washing parameters, the mathematical planning of the experiment was performed using Latin squares. Experimental data was processed using mathematical statistics in the Matcad package.

Results and discussion. The influence of Sles 70 concentration in the washing solution in the range of 0.5-3.5 $\mathrm{g} / \mathrm{dm}^{3}$, the hydromodule $10-50$, the temperature $20-50{ }^{\circ} \mathrm{C}$ and the duration of washing 2 to 32 minutes were determined for extraction of extractives from sheep wool into a washing solution.

The rational parameters of washing of fine-wool hair are revealed, influential factors are determined. The possibility of reducing the amount of water used during washing is studied. A regression equation is obtained that approximates the effect of normalized factors on the refractive index $\mathrm{n}\left(n_{\mathrm{D}}{ }^{20}\right)$ of waste water. Three essential and significant factors on the amount of extracted substances extracted in the washed solution are selected. The most influential factor on the refractive index of the spent washing solution is the temperature. Further on the significance of the effect is the hydromodule, with the temperature and the hydraulic module exhibit a measurable effect on the refractive index. The less important factor is the duration of the washing process. The concentration of detergent Sles 70 was an ineffective factor in the process of washing the wool, since the detergent was sufficient to form a micelle in a clean solution.

Conclusions. It is determined that within the limits of the investigated range, the rational mode is as follows: washing at a temperature of $40{ }^{\circ} \mathrm{C}$ and a hydromodule of process 10 (the ratio of aqueous solution: wool 10:1) for a duration of 10 minutes washing solution Sles 70 at a concentration of $1 \mathrm{~g} / \mathrm{dm}^{3}$. 


\section{Introduction}

Purified wool grease (E-913 lanolin) is widely used in the manufacture of food, perfume and cosmetics and special products and preparations [1,2].

The sheep's wool is trimmed after trimming and sent for purification on the primary treatment. The primary treatment of wool includes dry and wet stages $[1,8]$. The dry stage of primary treatment is intended to remove dry particles from the runes: lumps of earth or sand, straw. Dry cleaning is carried out on tipping machines, which do not loosen the fleece's fibers but only shaking, reducing the contamination of the wool. Wet cleansing involves the sequential movement of wool in several baths (barks) with detergent solutions for the removal of such substances: vein of wool, sand, residues of feed and excrement, pigments and other dirt [6-8].

Washing the wool can be done in washing machines that use a different washing principle. For a van washing machine, it is important to maintain the ratio of water: wool or hydromodule of the washing process. For a reciprocating machine, the pressure of the water at the outlet of the nozzles is important, however, the fiber is dumped under the high pressure of water. Better washing of dirt from wool is characteristic for the bathroom machine. The mixing of the contents of the bath with the robbery mechanism is more intense than with the harrow mechanism, due to the reduction of the number of so-called "dead" zones with standing liquid detergent [14].

Primary treatment of wool includes tepid, wet cleaning, which involves soaking, washing and rinsing, and drying. Washing of wool is carried out in aqueous solution of soap and soda for dipping the wool into a solution and successively moving in several baths, which change the temperature regime and the concentration of detergent solutions. Soaking is carried out in $0.1-0.2 \%$ solution of sodium carbonate (soda ash) with a temperature of $35-40{ }^{\circ} \mathrm{C}$ for $30-40$ minutes for the mass ratio of the solution to the wool from 25 to 30 to 1 . After soaking the wool is pressed. Washing is carried out sequentially in two working chambers of a washing machine in $0,2-0,3 \%$ solution of commercial soap and $0.2-0.3 \%$ solution of sodium carbonate at a temperature of $45-50{ }^{\circ} \mathrm{C}$ for $5-10$ minutes for a mass ratio of solution to wool 25 to 30 to 1 . After washing in each cell wool is pressed. Next, rinsing is carried out sequentially in two working chambers of the washing machine and spin after passing the wool of each chamber, and rinsing is performed at a temperature of $35-40{ }^{\circ} \mathrm{C}$ for $5-7$ minutes in the first chamber and at a temperature of $20-25{ }^{\circ} \mathrm{C}$ for 3 to 5 minutes in the second chamber. After wet processing, the wool is dried in the dryer at an air temperature of $75-85{ }^{\circ} \mathrm{C}$ to a final moisture content of wool of $12-18 \%$. The spent cleaning solutions of the final stages of processing after filtration are used for further wool washing [UA $55426 \mathrm{U}, 10.12 .2009]$. In this way, the waste water that contains grease, dirt and which consumes $125-150$ parts by weight to 1 part by weight of wool is obtained.

In order to increase the capacity of the washing machine and reduce the hanging particles in the next bath, in comparison with the previous one, it is suggested before irrigation with a washing solution with a temperature of $1-25{ }^{\circ} \mathrm{C}$ above the solution temperature in the washing machine chamber and to prevent free draining of the excess portion of the solution towards the spindle shafts [RU $2193081 \mathrm{C} 1,20.11 .2002]$.

The reaction movement of the wool and the detergent solution reduces the amount of waste (waste water) and increases the concentration of suspended particles of dirt in the first chamber of the washing machine [RU 2228975 C1, 20.05.2004]. Moreover, the amount of waste water is regulated by the concentration of dirt in the first chamber of a washing machine [RU $2365685 \mathrm{C} 1,27.08 .2009]$, or by the size of the counterflow, which is 
set by adjusting the flow through the overflow pipes and visually fixed on the calibration openings of the drain tank installed at the beginning of the first washing machine chamber [RU 2441946, 10.12.2012].

During intense mechanical mixing during wool washing can be dumped. Washing dirty wool requires the use of water, which, after wool cleaning, requires additional treatment to separate fat from dirt. Reducing water consumption and preventing the removal of fibers was achieved by mechanical additional extraction of wool in a washing liquid [9].

Intensification of wool washing was carried out by repeated pressing of wool while washing and loosening it, bubbling the solution with air. Washing the wool in a bath with multiple pressing allows you to reduce the volume of sewage twice [10].

Extrusion of wool after each technological operation (soaking, washing, rinsing) reduces the consumption of water and detergents in 1.2-1.5 times. A small-sized plant for primary wool processing for agricultural enterprises has been developed, which includes a spinning roller for pressing wool after soaking and a washing machine, in which there are two washing chambers and two for rinsing, and moves the wool from the chamber to the next chamber after it is squeezed [12].

The reduction of the number of baths for washing the wool reaches the previous one before washing with wool treatment by high voltage electrical discharges [UA $38562 \mathrm{U}$, 12.01.2009; 16].

Intensification of wool cleaning is carried out by lowering the temperature of the detergent solution and water for rinsing the wool and simultaneously treating the wool with high voltage electric discharges [UA $48930 \mathrm{U}, 12.04 .2010]$. Also, the processing of wool fibers is carried out by high voltage electrical discharges before washing and dyeing to increase the sorption properties of wool, although, after processing with electrond rigid nonlinear volumetric cavitation, the weight of wool is reduced [UA $111316 \mathrm{U}, 10.11 .2016$; $11]$.

During the washing of wool, an electro-hydraulic impact is used which is created in the field between the grounded conveyor which is immersed in the washing solution and by which the wool is transported, and the electrodes supplied with current pulses from the pulse current generator [RU $2049178 \mathrm{C1}, 27.11 .1995]$.

When wool is washed, an ultrasound of $5-22 \mathrm{kHz}$ with an intensity of $1-2 \mathrm{~W} / \mathrm{cm}^{2}$ using at least two hydrodynamic magnetostrictive transducers is used, and the washing solution is applied to the washing chamber under pressure of 4-7 atm, which provides mixing of the solution and the wool [UA $35834 \mathrm{~A}, 16.01 .2001$ ].

Wool washings are carried out using ultrasound in a V-shaped cylinder with a hollow shaft, with flat acoustic emitters fixed on the acoustically rigid walls of the cylinder, as well as initiating the washing of the dirt, replacing the washing solution and then removing the wool oil from the wool [UA 30059 A, 15.11.2000]. The use of flat hydrodynamic emitters in industrial washing machines is placed over a layer of wool immersed in a washing solution and placed between the mesh bands of two conveyors that move the wool in a washing machine [UA $54270 \mathrm{U}, 10.11 .2010 ; 13$ ].

There are several interpretations of the use of ozone or air ions in air to improve the quality of wool due to the restoration of cross-fiber fiber bonds and the increase of ureabisulfite solubility of wool [RU $2228974 \mathrm{C1}, 20.05 .2004]$ or for destruction of zhiropt and organic pollutants [UA $56564 \mathrm{~A}, 15.05 .2003$ ].

Washing of wool is carried out in an alkaline fraction of hydrolyzed water at $\mathrm{pH}$ 9.0-9.5, followed by treatment in an acidic fraction of hydrolyzed water at $\mathrm{pH} 5.0-6.0$ and at a temperature of $45-50{ }^{\circ} \mathrm{C}$ without the use of detergents [UA $29671 \mathrm{~A}, 15.11 .2000$ ]. 
For washing the wool use 2-3\% water mildew solutions [UA 55426 U, 10.12.2010; 8] and aqueous solutions with synthetic detergents [UA 32398, 12.05.2008; UA $32960 \mathrm{U}$, 10.06.2008; UA $57000 \mathrm{U}, 10.02 .2011]$.

Consequently, wool washing is carried out in a water environment in order to remove contaminants and wool grease (zhiropot). After washing the wool accumulates the waste water that is treated to remove from it the wool fat.

Cleaning the wool is necessary for the removal of mineral and organic contaminants, adhered to woolen fibers. Apply drying (dry mechanical cleaning from dust, earth, straw, forage) and soaking and washing (wet cleaning). Washing is carried out necessarily. While washing with dirt, they take off part of the wax, or the so-called zhiropt, from the surface of the fiber [UA $105905 \mathrm{U}, 11.04 .2016$; UA $105906 \mathrm{U}, 11.04 .2016$; UA $114836 \mathrm{C} 2$, 10.08.2017; UA 114837 C2, 10.08.2017]. Search for detergents for washing wool is also relevant today. Requirements for detergent are as follows: the product should not reduce the quality of the wool fiber (to be chemically inert to the wool), its consumption should be minimal (critical concentration of micelles - as small as possible) $[3,5]$.

\section{Materials and methods}

Sles 70 was washed with wipes. In order to find rational wool washing parameters, the mathematical planning of the experiment in Latin squares was used. This plan of experiment declares the absence of inter-factor influences. This involves the choice of independent factors and the use of the regression equations of the response of the change in factors to find the optimal value of the factor in the selected range of variation. Each experiment experiment performed in triple repetition. Among the factors that were used to clean the wool during soaking, the concentration of Sles 70 in the washing solution, the hydrodilution (water ratio: dry wool), temperature, and duration was investigated. In response to changes in factors, the refractive index of waste water was chosen.

Experimental data was processed using mathematical statistics in the Matcad package.

\section{Results and discussion}

The purpose of our study was to find the rational parameters of washing fine-wool hair. To achieve the goal, the factors influencing the process of extracting extractives in the washing solution were determined, and the possibility of reducing the amount of water used during washing was studied. The washing solution was prepared by dissolving an anionic detergent sodium laureth sulfate (Sles 70), replacing the classical alkaline solution solution with a solution with a neutral $\mathrm{pH}$ of the medium. Solutions up to $3 \%$ Sles 70 have a pH of 6.5-9.5. The critical concentration of micelles (CCM) at a temperature of $20^{\circ} \mathrm{C}$ for Sles 70 is $0.55 \mathrm{~g} / \mathrm{dm}^{3}[4,15]$. Sles 70 is the main ingredient in the hair shampoo formulation.

The influence of Sles 70 concentration in the washing solution in the range of $0.5-3.5$ $\mathrm{g} / \mathrm{dm}^{3}$, the hydromodule $10-50$, the temperature $20-50{ }^{\circ} \mathrm{C}$ and the duration of washing 2 to 32 minutes were determined for extraction of extractives from sheep wool into a washing solution.

The plan of incomplete factor experiment is presented in the table 1. 
Table 1

Planning a partial quotient experiment in Latin squares in physical quantities of factor levels

\begin{tabular}{|c|c|c|c|c|}
\hline $\begin{array}{c}\text { Experiment } \\
\text { No. }\end{array}$ & $\begin{array}{c}\text { Concentration Sles 70, } \\
\mathrm{g} / \mathrm{dm}^{3}\end{array}$ & $\begin{array}{c}\text { Hydraulic } \\
\text { Module }\end{array}$ & $\begin{array}{c}\text { Temperature, } \\
{ }^{\circ} \mathrm{C}\end{array}$ & $\begin{array}{c}\text { Duration, } \\
\text { min. }\end{array}$ \\
\hline 1 & 1.5 & 55 & 40 & 2 \\
\hline 2 & 3.5 & 25 & 20 & 22 \\
\hline 3 & 0.5 & 40 & 30 & 32 \\
\hline 4 & 2.5 & 10 & 50 & 12 \\
\hline 5 & 3.5 & 55 & 50 & 32 \\
\hline 6 & 1.5 & 40 & 20 & 12 \\
\hline 7 & 2.5 & 25 & 30 & 2 \\
\hline 8 & 0.5 & 10 & 40 & 22 \\
\hline 9 & 1.5 & 10 & 30 & 22 \\
\hline 10 & 0.5 & 25 & 50 & 2 \\
\hline 11 & 3.5 & 40 & 40 & 12 \\
\hline 12 & 2.5 & 55 & 20 & 32 \\
\hline 13 & 0.5 & 55 & 20 & 12 \\
\hline 14 & 2.5 & 40 & 40 & 22 \\
\hline 15 & 1.5 & 25 & 50 & 32 \\
\hline 16 & 3.5 & 10 & 30 & 2 \\
\hline
\end{tabular}

The results of a partial factor experiment are presented in the table 2.

Table 2

Average response to changing factors in the selected range

\begin{tabular}{|c|c|}
\hline Experiment No. & Refractive index \\
\hline 1 & 1.3340 \\
\hline 2 & 1.3338 \\
\hline 3 & 1.3338 \\
\hline 4 & 1.3344 \\
\hline 5 & 1.3340 \\
\hline 6 & 1.3336 \\
\hline 7 & 1.3340 \\
\hline 8 & 1.3342 \\
\hline 9 & 1.3342 \\
\hline 10 & 1.3336 \\
\hline 11 & 1.3340 \\
\hline 12 & 1.3336 \\
\hline 13 & 1.3340 \\
\hline 14 & 1.3340 \\
\hline 15 & 1.3338 \\
\hline 16 & 1.3342 \\
\hline
\end{tabular}




\section{— Food Technologies}

To compare the influence of the investigated factors, the values of the levels of factors were normalized.

Correlation and regression dependence of the index of refraction on the change of factors in the studied range was established.

The regression equation, which approximates the effect of normalized factors on the refractive index $n$ of the treated wastewater:

$$
n=-0,0001 x_{1}{ }^{2}-0,0007 x_{1}-0,0001 x_{2}{ }^{2}+0,0006 x_{2}-0,00007 x_{3}{ }^{2}+0,0003 x_{3}+4,0016,
$$

where $\quad \mathrm{x} 1-$ wool wash temperature in the normalized sense; $\mathrm{x} 2$ - hydrological washing hair in normalized terms; $x 3$ - the duration of wool washing in the normalized sense.

The coefficients in the regression equation are congruent and significant. The effect of the duration of wool washing is less significant, albeit an influential factor, in comparison with the influence of temperature and the hydromodule of washing in the studied range of variation of factors. The obtained regression equation describes the effect of temperature on extracting extractives in a washing solution with a determination coefficient of $99.4 \%$, the effect of the hydrodule represents $89.6 \%$ of the experimental data, and the effect of duration in the regression equation reproduces $87.1 \%$ of the actual values of the factor response.

From the regression equation, it follows that the influence of extracting extractives during washing in the solution of solutions can be ranked in order of decreasing their effect on the process: washing temperature, hydromodule (ratio of water: wool), duration of washing process. The concentration of detergent in the solution exceeded its CCM, so the effect of this factor did not manifest.

On the basis of the regression equation, the surface of the response was constructed, considering the factors that are in pairs, which have an influence on the extraction of the extractives in the washing solution during washing.

In Figure 1 shows the response plane for the change of the hydromodule and the temperature taken in the normalized form. On the plane of the same color, the areas with the same range of refractive index values of the worked-out detergent solution were observed. 


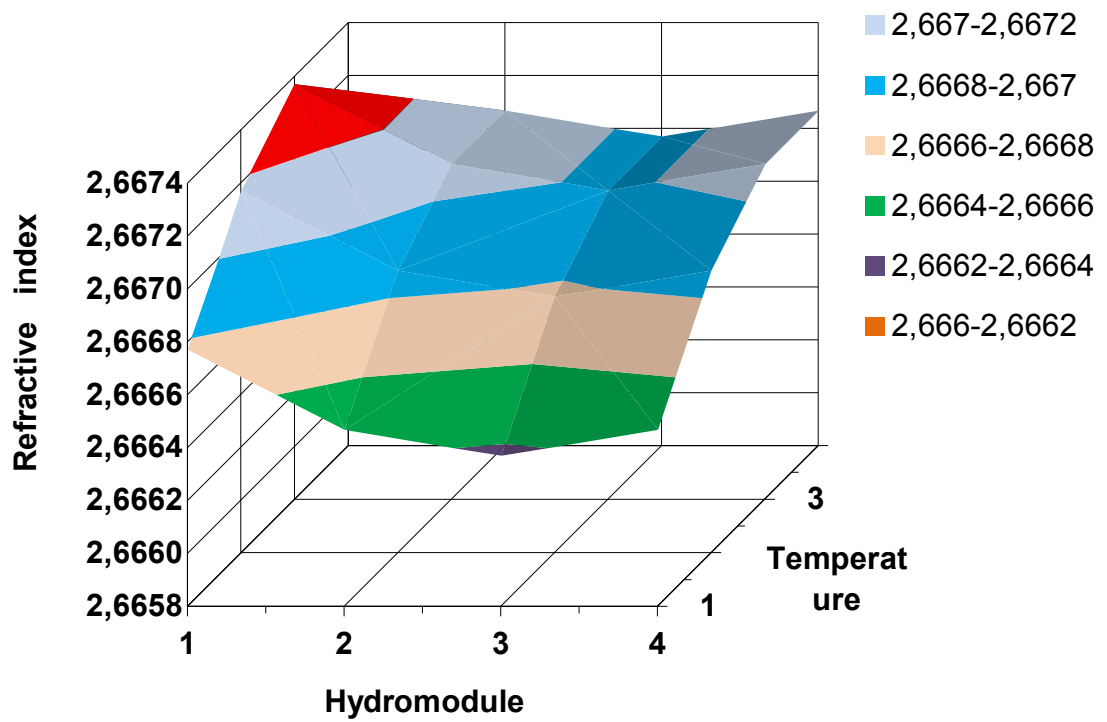

Figure 1. The response plane of the values of the refractive index of the spent washing solution for the change of hydromodule and temperature taken in the normalized form

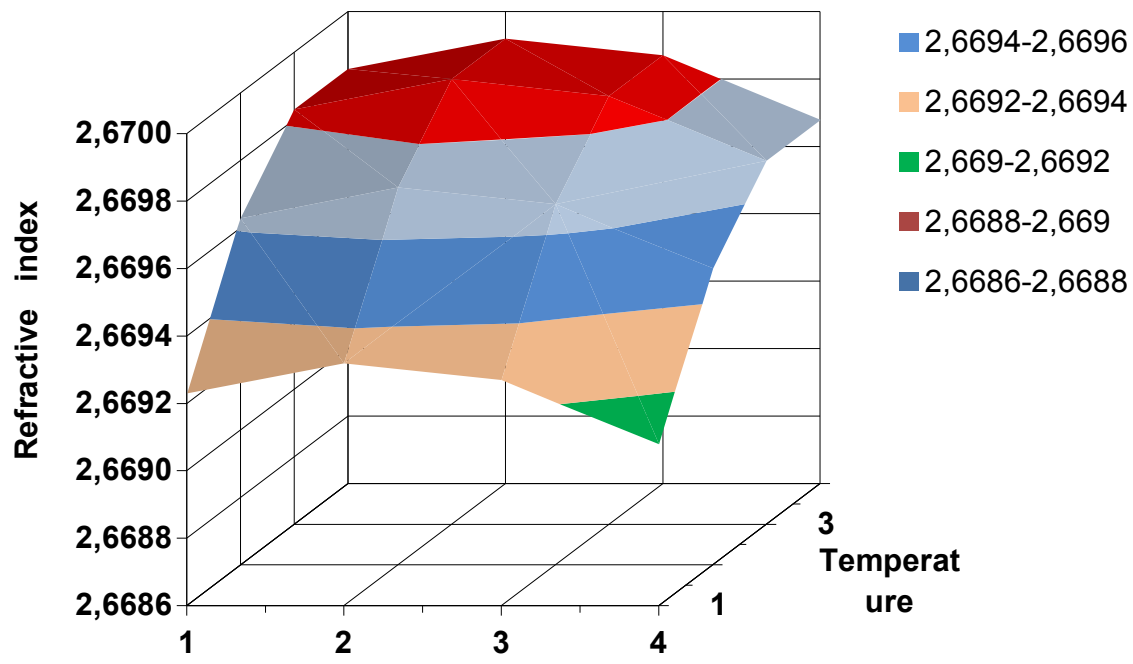

\section{Duration}

Figure 2. The response plane of the values of the refractive index of the spent washing solution for the change of temperature and duration of washing taken in the normalized form 
From Figure 1 shows that the greatest value of the refractive index of the detergent solution is achieved for the normalized values of the hydromodule 1 and temperature 3 , which correspond to the physical values of the hydrodule 10 respectively and the temperature of $40^{\circ} \mathrm{C}$. Consequently, the most extractive substances in the washing solution accumulate in the hydromodule 10 and the temperature of $40^{\circ} \mathrm{C}$.

Wool wash for 22 minutes reaches equilibrium values of the content of extractives in the washing solution. Extending the duration of washing does not increase the refractive index of the detergent solution, as seen from the Figure 2. Wool washing in Sles 70 solution at temperatures in the range of $20-44{ }^{\circ} \mathrm{C}$ for 22 minutes and extracts most of the extractives for longer.

The hydromodule 10 removes the most extractive substances from the wool in the washing solution. Consideration of the effects of the hydromodule and the duration of washing on the value of refractive index of the detergent solution revealed the sufficiency of varying the duration of the washing process in the range of 12-22 minutes for the hydromodule 10 (Figure 3).

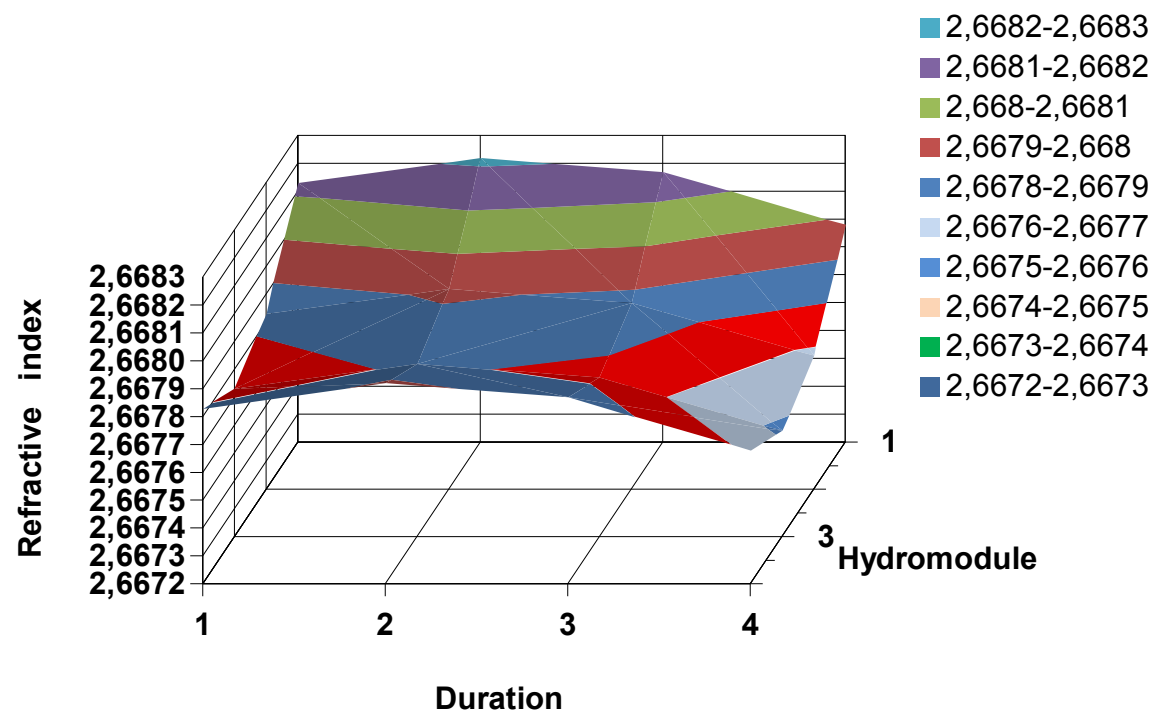

Figure 3. The response plane of the values of the refractive index of the spent washing solution for the change of hydromodule and duration of washing taken in the normalized form

Consequently, the use the ratio of aqueous solution: wool 10:1 is optimal, which indicated the expediency reducing the amount o water during wool washing. 


\section{Conclusion}

The influence of the concentration of detergent in the washing solution, the hydromodule, the temperature and duration of washing on the refractive index of the washed waste solution obtained after wool washing was investigated. The refractive index indirectly indicates the amount of extracts extracted from the wool removed from the wool.

Three essential and significant factors on the content of recovered extractives in the washed solution were identified. The most influential factor on the refractive index of the spent washing solution is the temperature. Further on the significance of the effect is the hydromodule, with the temperature and the hydraulic module exhibit a measurable effect on the refractive index. The less important factor is the duration of the washing process. The concentration of detergent Sles 70 was an ineffective factor in the process of washing the wool, since the medium was taken sufficiently to form a micelle in a washing solution.

According to the results of the mathematical processing of the incomplete factor experiment planned by the Latin squares method, it is determined that within the limits of the investigated range, the rational mode of washing is as follows: washing at a temperature of $40{ }^{\circ} \mathrm{C}$ and the hydromodule of the process 10 (ratio of aqueous solution : wool 10:1) for a duration of 10 minutes washing solution Sles 70 at a concentration of $1 \mathrm{~g} / \mathrm{dm}^{3}$.

\section{References}

1. Amit Sengupta, Jagadananda Behera (2014), Comprehensive view on chemistry, manufacturing \& applications of lanolin extracted from wool pretreatment, American Journal of Engineering Research (AJER), 3(07), pp. 33-43.

2. Lopez-Mesas M., Carrillo F., Gutierrez M., Crespi M. (2007), Alternative metods for the wool wax extraction from wool scouring wastes, Grasas y aceites, 58(4), pp. 402-407.

3. Oseiko N., Levchuk I., Romanovska T., Olishevsky V. (2015), Ecologic and economic efficiency comparison of lanolin extraction methods, Special issue of Journal of EcoAgriTourism (Transilvania University Press, Brasov, Romania), p. 167.

4. Oseiko N., Romanovska T., Lyahovetskiy D. (2016), Study critical micelle concentration of washing solutions, Food Science for Well-being: Book of Abstracts 8th Central European Congress on Food (CEFood 2016), Kyiv, 23-26 May 2016, p. 225.

5. Oseiko N., Romanovska T., Marinin A., Levchuk I. (2015), The properties of wool grease, Special issue of Journal of EcoAgriTourism (Transilvania University Press, Brasov, Romania), p. 168.

6. Oseiko N., Romanovska T., Tkachenko Y. (2016), Technological aspects for fat wool, Food Science for Well-being: Book of Abstracts 8th Central European Congress on Food (CEFood 2016), Kyiv, 23-26 May 2016, p. 226.

7. Romanovska Tetiana, Oseiko Nick (2016), The features of primary processing of wool, Proceedings of the International Conference: Modern technologies, in the food industry - 2016; international conference MTFI-2016, 20-22 october, Kishinev: Tehnical University of Moldova, pp. 266-267.

8. Gusev V.E. (1977), Syyr'e dlja sherstjanyyh y netkanyyh yzdelyj y pervychnaja obrabotka shersty, Legkaja yndustryja, Moskva. 
9. Zaporoshhenko K.L., Basheeva L.A., Grek O.V. (2004), Yssledovanye yntensyvnoj tehnologyy promyyvky shersty, Sbornyk nauchnyyh trudov Stavropol'skogo NYY zhyvotnovodstva y kormoproyzvodstva, 2(2-2), 5 p.

10. Zaporoshhenko K.L., Myroshnychenko S.Y., Basheeva L.A. (2009), Na puty yntensyfykacyy tehnologyy vodnoj promyyvky shersty, Sbornyk nauchnyyh trudov Stavropol'skogo NYY zhyvotnovodstva y kormoproyzvodstva, 3(3), 9 p.

11. Kunyk A.N., Semeshko O.Ja., Asauljuk T.S., Sarybekova Ju.G., Mjasnykov S.A. Razrabotka dvuhstadyjnoj tehnologyy ochystky shersty metodom vyysokoэnergetycheskoj dyskretnoj obrabotky (2016), Vostochno-Evropejskyj zhurnal peredovyyh tehnologyj, 4(10_82), pp. 36-43.

12. Lykhodid V.V., Pavlenko S.I., Ivlyev V.V., Sukharl'ov V.O. (2015), Analiz tekhnolohiy ta tekhnichnykh zasobiv dlya pervynnoyi obrobky vovny $\mathrm{v}$ umovakh sil's'kohospodars'kykh formuvan', Visnnyk Kharkivs'koho nats. tekhnichnoho un-tu sil's'koho hospodarstva im. Petra Vasylenka, 157, pp. 169-179.

13. Moroz A.N., Sasymova N.A. (2010), Teoretycheskoe obosnovanye parametrov ustrojstv dlja pervychnoj obrabotky shersty v akustycheskom pole, Energosnabzhenye. Energetyka. Energoaudyt, 9(79), pp. 51-56.

14. Muntjan V.A. (2010), Analyz tehnologycheskyh processov y ustrojstv dlja pervychnoj obrabotky shersty, Energosnabzhenye. Energetyka. Energoaudyt, 1(71), pp. 62-65.

15. Oseyko M.I., Romanovs'ka T.I., Lyakhovets'kyy D.O. (2016), Kharakterystyka myynykh rozchyniv pervynnoyi obrobky vovny \{Description of washing solutions for primary wool processing\}, Naukovi pratsi NUKhT, 22(5), pp. 245-249.

16. Sarybekova Ju.G. (2009), Prymenenye эlektrorazrjadnoj nelynejnoj ob\#emnoj kavytacyy v processe ochystky sherstjanogo volokna, Vostochno-Evropejskyj zhurnal peredovyyh tehnologyj, 4(9.40), pp. 43-46. 